\title{
Glycoprotein asporin as a novel player in tumour microenvironment and cancer progression
}

\author{
Dana Simkovaa , Gvantsa Kharaishvilia , Eva Slabakovaa ${ }^{b}$ Paul G. Murrayc, Jan Bouchal ${ }^{a}$
}

Background. Small leucine rich proteoglycans (SLRPs), major non-collagen components of the extracellular matrix $(E C M)$, have multiple biological roles with diverse effects. Asporin, a member of the SLRPs class I, competes with other molecules in binding to collagen and affects its mineralization. Its role in cancer is only now being elucidated.

Methods. The PubMed online database was used to search relevant reviews and original articles. Furthermore, altered asporin expression was analysed in publicly available genome-wide expression data at the Gene Expression Omnibus database.

Results. Polymorphisms in the N-terminal polyaspartate domain, which binds calcium, are associated with osteoarthritis and prostate cancer. Asporin also promotes the progression of scirrhous gastric cancer where it is required for coordinated invasion by cancer associated fibroblasts and cancer cells. Besides the enhanced expression of asporin observed in multiple cancer types, such as breast, prostate, gastric, pancreas and colon cancer, tumour suppressive effects of asporin were described in triple-negative breast cancer. We also discuss a number of factors modulating asporin expression in different cell types relevant for alterations toing the tumour microenvironment.

Conclusion. The apparent contradicting tumour promoting and suppressive effects of asporin require further investigation. Deciphering the role of asporin and other SLRPs in tumour-stroma interactions is needed for a better understanding of cancer progression and potentially also for novel tumour microenvironment based therapies.

Key words: asporin, polymorphism, cancer, gastric, breast, prostate, adipose tissue, miRNAs

Received: May 4, 2016; Accepted with revision: July 8, 2016; Available online: September 5, 2016

http://dx.doi.org/10.5507/bp.2016.037

${ }^{a}$ Department of Clinical and Molecular Pathology and Institute of Molecular and Translational Medicine, Faculty of Medicine and Dentistry, Palacky University, Olomouc, Czech Republic

${ }^{b}$ Department of Cytokinetics, Institute of Biophysics, Academy of Sciences of the Czech Republic, v.v.i., Brno, Czech Republic

'Institute of Cancer and Genomic Sciences, University of Birmingham, Birmingham, UK

Corresponding author: Jan Bouchal, e-mail:jan.bouchal@gmail.com

\section{INTRODUCTION}

The extracellular matrix (ECM) is a dynamic structure providing physical and metabolic support, organisation and orientation for tissues ${ }^{1,2}$ as well as supplying crucial elements in cell survival i.e. growth factors, inflammatory molecules, and immune soluble mediators ${ }^{3}$. The ECM consists of a plethora of proteins with varying structure and function ${ }^{4}$. Among others, the small leucine rich repeat proteoglycan family (SLRPs) constitutes an important group of ECM proteins, present in most extracellular matrices ${ }^{5}$.

Small leucine rich repeat proteoglycans comprise 18 distinct members, subdivided into 5 classes based on chromosomal organization, and homology at gene and protein level ${ }^{5}$. The SLRP family is characterized by core leucine-rich repeats (LRR), N-terminally localized cysteine clusters and C-terminal ear repeat motif. SLRPs are also characterized by the nature of their structural components, i.e. conserved protein core and various types of attached glycosaminoglycan chains: keratan, chondroitin, dermatan sulphate and heparan sulphate ${ }^{6}$. The crescent shape is typical for SLRPs, where due to polarized struc- ture, $\beta$ sheets are aligned on the concave surface, while $\alpha$ helices form the convex face ${ }^{7}$.

SLRP class I comprises 5 members: decorin, biglycan, asporin (ASPN), extracellular matrix proteins 2 and X. Decorin and biglycan are widely studied proteins whose roles, structure and function have been reviewed elsewhere $^{7-9}$. ASPN has been intensively studied in bone and joint diseases, where it is associated with osteoarthritis, invertebral disc disease and hypochondrogenesis ${ }^{10-13}$.

\section{STRUCTURE AND FUNCTION}

Asporin was identified by three research groups in 2001 (ref. ${ }^{14-16}$ ). The gene spans $26 \mathrm{~kb}$ on chromosome 9q22 and comprises 8 exons. ASPN shows amino acid identity with decorin $(54 \%)$ and biglycan $(60 \%)\left(\right.$ ref. $\left.{ }^{17}\right)$. The core region, typical for the whole SLRP family, consists of 12 LRRs (ref. ${ }^{14,15}$ ). Whereas decorin and biglycan are proteoglycans, defined as proteins with very high polysaccharide content, the ASPN molecule is different because it lacks multiple glycosylation regions, crucial for glycan attachment; and therefore it is not 
strictly a proteoglycan. Nevertheless, ASPN is a glycoprotein due to one $\mathrm{N}$-glycosylation site at ASN ${ }^{281}$ and a potential O-glycosylation site at Ser 54 ( ref. $\left.^{15}\right)$. Unlike decorin or biglycan, ASPN lacks chondroitin or dermatan sulphate chains. Instead it carries an aspartic acid repeat (D-repeat) unit, whose numbers range from 8 to 19. Typically, the ASPN molecule has 13 aspartic acid repeats. The polymorphic allele with 14 repeats has been found to be associated with knee osteoarthritis, which is very prevalent in Eastern Asian populations and less so in Europeans ${ }^{18-25}$. Polymorphism in D-repeat length was also observed in ankylosing spondylitis and lumbar disc degeneration in East Asian populations ${ }^{26,27}$. Another genetic polymorphism (intronic rs 13301537, between exons 3 and 4) has been associated with progression of hand osteoarthritis in Europeans. However the molecular mechanism is unclear ${ }^{28}$.

A crucial characteristic of ASPN is its ability to bind collagens. The aspartic acid rich $\mathrm{N}$-terminal region and central part of the ASPN molecule bind type II collagen ${ }^{17}$ while collagen I is bound by the central region, LRR1012. ASPN significantly inhibited collagen fibrilogenesis in vitro in a dose dependent manner ${ }^{29}$. ASPN competes with decorin in binding the same sites and this competition may have a role in regulating the development of the ECM. ASPN N-terminal polyaspartate domain also binds calcium, and works in concert with other domains in order to initiate the mineralization of collagen ${ }^{29}$. Although Yamada et al. ${ }^{30}$ reported ASPN as a negative regulator of periodontal ligament mineralization, another group recently supported the crucial role of ASPN in collagen mineralization during odontogenic differentiation of human dental pulp stem cells ${ }^{31}$. Further investigation is needed to clarify ASPN functions in different cell types and contexts.

\section{ASPORIN EXPRESSION AND ITS REGULATION IN NORMAL TISSUES AND NON-CANCER DISEASES}

Broad screening of $A S P N$ mRNA revealed its expression in a variety of human tissues with high levels in osteoarthritic articular cartilage, aorta, uterus and heart ${ }^{15}$. Moderate expression levels are found in mammary gland and small intestine, while no expression was found in the central nervous system, spleen and thymus. A similar $A S P N$ expression pattern was observed in fetal tissues ${ }^{15}$. It was also demonstrated that $A S P N$ is expressed in the periodontal ligament. This is the origin of asporin 's other name- PLAP1 (peridontal ligament associated protein 1) (ref. ${ }^{16,30}$ ). Lee et al. ${ }^{31}$ demonstrated $A S P N$ expression in human dental pulp stem cells and its marked up-regulation during early odontogenic differentiation. The third group which discovered the asporin performed a detailed investigation using in situ hybridization analysis of sagitally sectioned mouse embryos at different stages of development $^{14}$. ASPN expression was prominent in the developing mouse skeleton, particularly in the perichondrium/ periosteum of cartilage/bone, and was also found in other specialized connective tissues such as tendon, sclera of the eye, and the connective tissue sheath surrounding muscle and dermis. Another study showed that expression of $A S P N, T G F-\beta 1$, and TGF- $\beta 3$ (transforming factor beta) in osteoblasts from subchondral bone and in particular osteophytes of osteoarthritic patients was higher than that of non-osteoarthritic patients ${ }^{32}$. High ASPN expression was also found in alveolar bone osteoblasts ${ }^{33}$. The family of small leucine rich repeat proteoglycans is commonly found in cartilage tissues where ASPN competes with other SLRPs in many processes ${ }^{34}$.

Landmark articles by Ikegawa et al. described an interaction between TGF $\beta$ and ASPN in chondrogenesis, during which TGF $\beta$ induced expression of $A S P N$ while recombinant ASPN suppressed TGF $\beta$ induction of aggrecan and collagen type II, markers of chondrogenesis ${ }^{18,35,36}$. ASPN also colocalized with TGF $\beta 1$ and blocked its binding to cell surface receptors of chondrogenic ATDC5 cells $^{36}$. Furthermore, $A S P N$ was up-regulated by BMP2 and 4 (bone morphogenetic protein) and down-regulated by FGF2 (fibroblast growth factor) in periodontal ligament cells ${ }^{30}$. Kalamajski et al. ${ }^{29}$ drew attention to the fact that TGF $\beta$ binds to many other matrix proteins, including decorin, fibromodulin, and the much more abundant collagen and fibronectin, which questions the physiological relevance of asporin as a TGF $\beta$ inhibitor. They suggest that ASPN directly regulates the initial deposition of hydroxyapatite in the collagen gap regions, rather than acting secondarily by inhibiting BMP-2 or TGF $\beta$ activity.

Up-regulation of $A S P N$ (both mRNA and protein) by TGF $\beta$ in chondrocytes has also been observed by Duval et al. ${ }^{37}$. On the other hand, $A S P N$ was down-regulated by pro-inflammatory cytokines IL-1 $\beta$ (interleukin 1 beta) and $\mathrm{TNF} \alpha$ (tumour necrosis factor alpha) which are also associated with osteoarthritis. This paradoxical regulation has also been observed for decorin and biglycan whose expression is also higher in osteoarthritis ${ }^{37}$. The transcription factor $\mathrm{Sp} 1$ up-regulates $A S P N$ expression and is able to bind to the $A S P N$ promoter ${ }^{37}$. Binding sites for the HOX-Runx (homeodomain-Runt domain) factors have been predicted for asporin, decorin, lumican and biglycan in their first intron ${ }^{37}$. The first intron of $A S P N$ also has a putative site for ETS-FKHD-STAT transcription factors (erythroblast transformation specific-forkhead-signal transducers and activators of transcription) (ref. ${ }^{38}$ ). As Smads are known to modulate transcription of Runx and HOX, whereas IL-1 $\beta$ induces ETS family expression, these transcription factors may be modulators of $A S P N$ expression $^{37}$. Importantly, IL $1 \beta$ is secreted by triple-negative breast cancer cells and down-regulates ASPN expression in cancer-associated fibroblasts (CAFs) $\left(\right.$ ref. $^{39}$ ), see below. One of the homeodomain transcription factors, CUX1 (cut-like homeobox 1; previous symbol CUTL1) has been described as a target of TGF $\beta$ and as an enhancer of breast cancer cell motility and invasiveness ${ }^{40}$. RNAi down-regulation of CUX1 in NIH3T3 mouse fibroblasts was associated with profound down-regulation of $A S P N$ (among top 20 genes), while other SLRP class II proteoglycans were up-regulated (lumican, fibromodulin and PRELP, proline arginine rich end leucine rich repeat pro- 
tein) (ref. $\left.{ }^{41}\right)$. However, the relationship between CUX1, TGF $\beta$ and ASPN in breast cancer is not clear as full genome analysis has not been performed for other cell types. $A S P N$ and anti-proliferative IGFBP5 (insulin-like growth factor binding protein) were up-regulated by transcription factor TonEBP (tonicity-responsive enhancer binding protein) in mouse embryonic fibroblasts and may be involved in renal adaptation to hypertonic stress ${ }^{40}$. Co-regulation of ASPN and IGFBP5 was also observed in alveolar bone osteoblasts $^{33}$.

Schaeffer et al..$^{42}$ focused on gene expression in the murine prostate rudiment at three time points during the first $48 \mathrm{~h}$ of exposure to androgen, which initiates proliferation and invasion of prostate epithelial buds into surrounding urogenital sinus mesenchyme. Seven genes (including $A S P N$ and Sox 9 transcription factor) were consistently up-regulated by androgen at all three time points. On the other hand, $A S P N$ mRNA (together with gremlin 1) was up-regulated in both benign prostate and cancer, three days after castration ${ }^{43}$. Similarly, $A S P N$ (along with decorin and lumican) was up-regulated following aromatase inhibitor treatment in primary breast cancer ${ }^{44}$.

$A S P N$ has been identified as a putative target of miR21 , which is frequently up-regulated in different cancers ${ }^{45}$. In this context, Li et al. showed that up-regulation of ASPN during osteogenic differentiation of peridontal ligament cells is associated with down-regulation of mir-21 and mir-101 (ref. $\left.{ }^{46}\right)$. Other microRNAs that down-regulate asporin were identified by microarray analysis in muscle fibre development in zebrafish ${ }^{47}$. Once the final fibre number is established, myotube formation is switched off and growth involves only an increase in fibre length and diameter (hypertrophy). Seven up-regulated miRNAs in the hypertrophic phenotype showed reciprocal expression with seven mRNA targets identified in miRBase Targets Database, including $A S P N$ which was the target of four miRNAs (dre-let-7e, dre-miR-155, dre-miR-193a and dremiR-365; dre stands for Danio rerio).

A search of the Gene Expression Omnibus ${ }^{48}$ revealed dramatic down-regulation of $A S P N$ in dermal fibroblasts following demethylation treatment with 5-aza-2 ' deoxycytidine (Table 1, Fig 1A, GDS2091) (ref. ${ }^{49}$ ). This down-regulation is probably due to endothelin-1 up-regulation, whose intron 1 is highly methylated in dermal fibroblasts. Furthermore, endothelin-1 treatment downregulated TGF $\beta 2$ and 3, which may be connected to the decreased ASPN levels in primary mouse dermal fibroblasts (Table 1, Fig 1B, GDS1980) (ref. ${ }^{49}$ ). Endothelin-1 is expressed in breast cancer cell lines which are negative for $A S P N$ expression (e.g. MDA-MB-231) (ref. $\left.{ }^{50}\right)$. High levels of $A S P N$ mRNA were found in the stroma of invasive ductal breast carcinoma where endothelin-3 was down-regulated ${ }^{51}$. With respect to histone methylation, high expression of ASPN was found in alveolar bone osteoblasts with high levels of $\mathrm{H} 3 \mathrm{~K} 9 \mathrm{me} 3$ (ref. ${ }^{33}$ ), but global loss of $\mathrm{H} 3 \mathrm{~K} 9$ trimethylation has been observed in several cancers $^{52}$.

Table 1. Regulation of asporin expression in different conditions and cell types.

\begin{tabular}{lclcll}
\hline Condition & Regulation & Type & Species* & Cell or tissue type & Ref. \\
\hline TGF-beta & $\uparrow$ & Both & $\mathrm{h}$ & chondrocytes & 18,37 \\
BMP2, BMP4 & $\uparrow$ & mRNA & $\mathrm{h}$ & periodontal ligament cells & 30 \\
Sp-1 & $\uparrow$ & Both & $\mathrm{h}$ & chondrocytes & 37 \\
TonEBP & $\uparrow$ & mRNA & $\mathrm{m}$ & embryonic fibroblasts & 41 \\
odontogenic differentiation & $\uparrow$ & Both & $\mathrm{h}$ & dental pulp stem cells & 31 \\
aromatase inhibitor & $\uparrow$ & mRNA & $\mathrm{h}$ & breast cancer & 44 \\
stiff Alvetex matrix & $\uparrow$ & Both & $\mathrm{h}$ & Hs578T cells and CAFs & 65 \\
serum free cultivation & $\uparrow$ & Both & $\mathrm{h}$ & Hs578T breast cancer cells & 65 \\
dihydrotestosterone & $\uparrow$ & mRNA & $\mathrm{m}$ & embryonic urogenital sinus & 42 \\
castration & $\uparrow$ & mRNA & $\mathrm{h}$ & prostate cancer & 43 \\
FGF2, PDGF-BB & $\downarrow$ & mRNA & $\mathrm{h}$ & periodontal ligament cells & 30 \\
CUX1 knock-out & $\downarrow$ & mRNA & $\mathrm{m}$ & NIH3T3 fibroblasts & 40 \\
miR-21, miR-101 & $\downarrow$ & mRNA & $\mathrm{h}$ & periodontal ligament cells & 46 \\
let-7e, miR-155, -193a, -365 & $\downarrow$ & mRNA & $\mathrm{z}$ & hypertrofic skeletal muscle & 40 \\
5-aza-2 '-deoxycytidin & $\downarrow$ & mRNA & $\mathrm{m}$ & fibroblasts, chondrocytes & GDS2091, 49 \\
endothelin-1 & $\downarrow$ & mRNA & $\mathrm{m}$ & dermal fibroblasts & GDS1980, 49 \\
IL-1beta, TNF alpha & $\downarrow$ & Both & $\mathrm{h}$ & chondrocytes & 37 \\
IL-1beta & $\downarrow$ & Both & $\mathrm{h}$ & breast CAFs & 39 \\
BMP4 & $\downarrow$ & Both & $\mathrm{h}$ & Hs578T breast cancer cells & 65 \\
\hline
\end{tabular}

${ }^{x}$ The evidence is provided for asporin regulation both at mRNA and protein levels or at mRNA level only.

* h, human; m, mouse; $\mathrm{z}$, zebra fish 


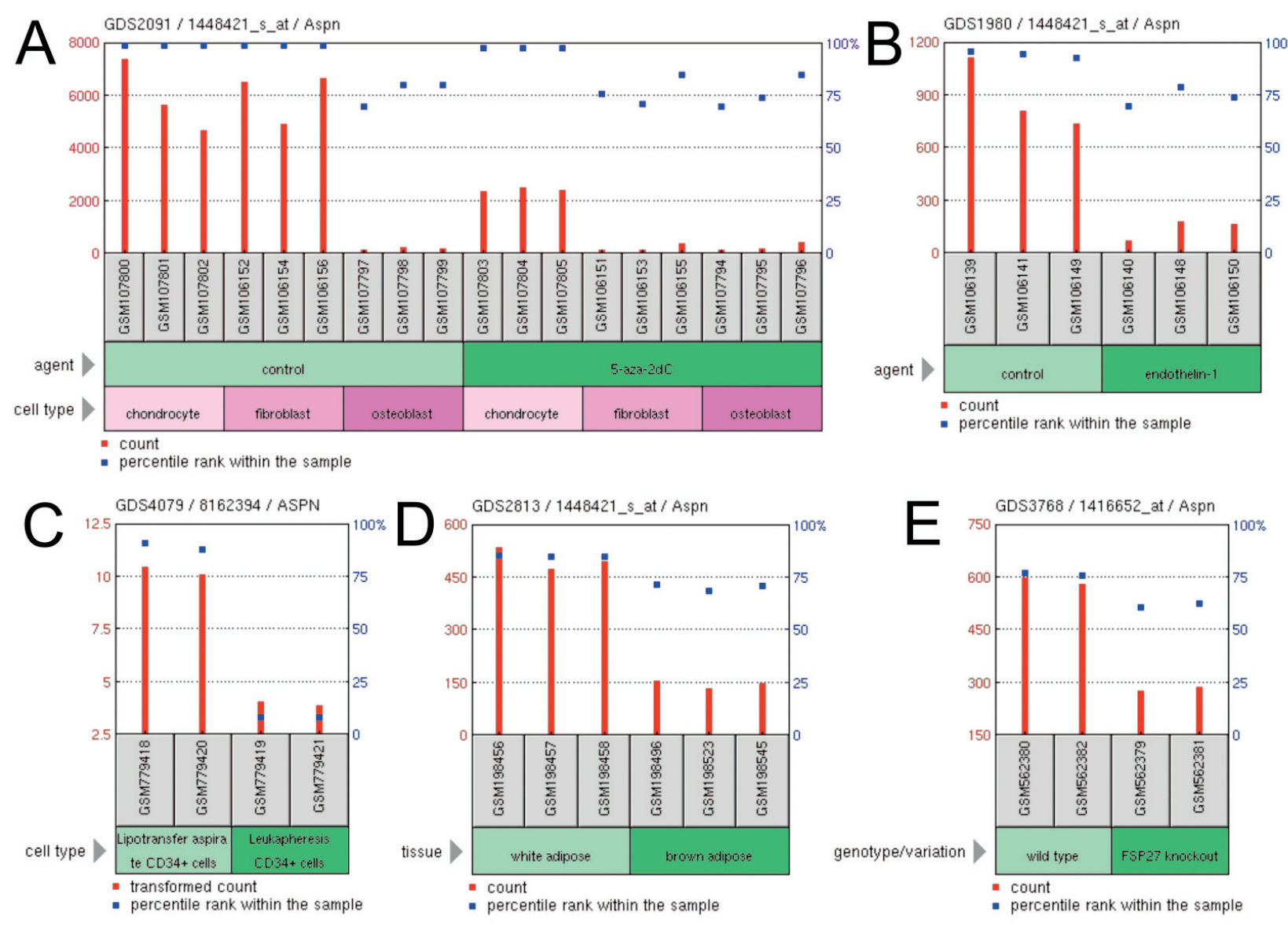

Fig. 1. A search of the Gene Expression Omnibus revealed modulation of asporin in specific conditions. $A S P N$ was downregulated by demethylation (A) or endothelin-1 (B) in a mouse model. Expression of $A S P N$ was higher in human CD34+ cells from white adipose tissue obtained by lipotransfer than in those cells obtained from bone marrow by leukapheresis (C). $A S P N$ expression was lower in brown adipose tissue (D) or upon FSP27 knock-out in white adipose tissue (E). Please refer to the main text for further detail.

\section{ASPORIN IN BREAST CANCER}

We identified asporin as a novel breast cancer related protein by microdissection and expression profiling ${ }^{53}$. It was up-regulated in invasive carcinomas, in particular lobular tumours, together with other extracellular matrix proteins. Higher expression of $A S P N$ in lobular (3 patients) compared to ductal cancer (32 patients) was also observed in other datasets ${ }^{54}$. The same group combined laser capture microdissection and gene expression microarrays to analyse 14 patient-matched normal breast epithelium, normal stroma, tumour epithelium and tumour-associated stroma specimens ${ }^{51} . A S P N$ was up-regulated in both tumour and DCIS (ductal carcinoma in situ) stroma in comparison to epithelium. Another study also observed enhanced $A S P N$ expression in invasive ductal carcinoma $^{55}$. Importantly, $A S P N$ was ranked among 22 genes specifically expressed in bone metastases of breast cancer $^{56}$ (without microdissection, samples with more than $80 \%$ tumour cells were analysed). Bone metastases are more frequent in ER/PR (oestrogen receptor/progesterone receptor) positive than in triple-negative breast cancers ${ }^{57}$. Hormone therapy with aromatase inhibitors up-regulates $A S P N\left(\right.$ ref. $^{44}$ ), which may be important for maintenance of residual breast cancer cells after this conventional therapy ${ }^{58}$.

A search of the Gene Expression Omnibus ${ }^{48}$, revealed high levels of $A S P N$ expression in white adipose-derived CD34+ cells in dataset GDS4079 (Fig 1C) (ref. ${ }^{59}$ ). This study reported human and murine white adipose tissue (WAT) as a very rich reservoir of $\mathrm{CD} 45{ }^{\circ} \mathrm{CD} 34^{+}$populations with endothelial differentiation potential, containing approximately 200 times more $\mathrm{CD} 45{ }^{\circ} \mathrm{CD} 34^{+}$cells $/ \mathrm{mL}$ than bone marrow. Compared with bone marrow-derived $\mathrm{CD} 34^{+}$cells mobilized in blood by granulocyte colonystimulating factor, purified WAT-CD $34^{+}$cells expressed similar levels of stemness-related genes, significantly increased levels of angiogenesis-related genes, and increased levels of fibroblast activation protein alpha, a crucial suppressor of anti-tumour immunity in mice ${ }^{60}$. In vitro, WAT-CD $34^{+}$cells generated mature endothelial cells and capillary tubes as efficiently as mature mesenchymal cells. Importantly, the co-injection of human WAT-CD $34^{+}$cells from lipotransfer procedures contributed to tumour vascularization and significantly increased tumour growth and metastases in several orthotopic models of human breast cancer in immunodeficient mice. Martin-Padura and colleagues emphasized the importance of gaining a 
better understanding the role of different WAT-derived cells used in lipotransfer for breast reconstruction in patients with breast cancer. There are higher $A S P N$ mRNA levels in white adipose tissue, compared to brown adipose tissue (GDS2813, Fig 1D) (ref. ${ }^{61}$ ). Diet-induced obese mice have higher $A S P N$ expression in WAT than controls (GDS3985) (ref. ${ }^{62}$ ), while FSP27 (Fat specific protein 27) knock-out causes browning of white fat, a healthy metabolic profile and decreased ASPN levels (GDS3768, Fig 1E) $\left(\right.$ ref. $\left.^{63,64}\right)$.

Recently, Maris and colleagues ${ }^{39}$ described ASPN protein as a fibroblast-derived TGF- $\beta 1$ inhibitor and a tumour suppressor associated with good prognosis in breast cancer. Detailed functional analyses showed that hormone receptor positive cell lines induced strong $A S P N$ expression (both mRNA and protein) in breast fibroblasts, while triple-negative breast cancer (TNBC) cells suppressed it. Soluble IL-1 $\beta$, secreted by TNBC cells, was found to be responsible for inhibiting ASPN in normal and cancerassociated fibroblasts. Importantly, induced ASPN expression in MDA-MB-468 cells significantly reduced their growth and metastatic capacity in a murine mode ${ }^{39}$.

During the publication process of this review, our original article on the dual role of asporin in breast cancer progression was accepted ${ }^{65}$. Briefly, according to our in silico search, high $A S P N$ expression associated with significantly better relapse free survival (RFS) in patients with low-grade tumors but RFS was significantly worse in patients with grade 3 tumors. We also showed that ASPN can be downregulated by bone morphogenetic protein 4 in Hs578T breast cancer cells while upregulation may be facilited by serum-free cultivation or by three dimensional growth in stiff Alvetex scaffold. Downregulation by shRNA inhibited invasion of Hs578T, while invasion of asporin-negative MDA-MB-231 and BT549 breast cancer cells through collagen type I was enhanced by recombinant asporin. Contradictory results on tumour promoting and suppressive effects of asporin require further investigation, in particular with respect to the aspartic acid repeat polymorphism (please see below).

\section{GASTRIC, PROSTATE AND OTHER CANCER TYPES}

The role of asporin in other cancers may be different as Satoyoshi et al. ${ }^{66}$ described its role in the coordinated invasion of scirrhous gastric cancer cells and CAFs. Similarly to hormone-receptor positive breast cancer cells, gastric tumour cells induced ASPN expression in CAFs that reciprocally stimulated their invasion causing rapid spread of the lesion. Mechanistically, ASPN was shown to activate Rac1 in both CAFs and cancer cells through an interaction with CD44. Up-regulation of $A S P N$ in gastric cancer in comparison to paired normal tissue has been previously reported by expression profiling ${ }^{67}$ and has also been reported to be expressed by gastric cancer cell lines to enhance their oncogenic properties ${ }^{68}$.

Highly specific and sensitive protein biomarkers measured in easily accessible samples are critical elements of personalized medicine. ASPN belongs to N-glycoproteins which can be effectively enriched from serum for proteomic analyses. Accordingly ASPN was identified as a candidate serum biomarker by mass spectrometry analysis of pancreatic ductal carcinoma tissues ${ }^{69}$. Another study identified $775 \mathrm{~N}$-glycoproteins from sera and prostate tissues of wild-type and Pten-null mice. Following bioinformatic prioritization, targeted proteomics was used to detect and quantify 39 human ortholog candidate biomarkers in the sera of prostate cancer patients and control individuals. Together with three other proteins - hypoxia up-regulated protein 1, cathepsin D and olfactomedin-4 - ASPN improved the discrimination of benign prostatic hyperplasia from localised prostate cancer ${ }^{70}$. Klee and colleagues $^{71}$ found $A S P N$ (mRNA and protein) among seven biomarkers up-regulated in both the tissues and serum of patients with advanced prostate cancer. Up-regulation of $A S P N$ was also found in microdissected androgen-independent prostate cancer cells ${ }^{72}$ and, similarly to breast cancer it was also highly expressed in bone metastases of prostate cancer ${ }^{73}$.

Recently, a large retrospective analysis was performed for germline $A S P N$ D-repeat-length polymorphism in 1,600 men who underwent radical prostatectomy compared to 548 non-cancer controls ${ }^{74}$. The homozygosity for the D13 allele was associated with reduced risk of metastatic disease after surgery, whereas heterozygosity for ASPN D13/ D14 or homozygosity for $A S P N$ D14 increased the risk of metastatic recurrence following surgery. Orthotopic xenografts established biological roles for ASPN D14 and $A S P N \mathrm{D} 13$ variants in metastatic prostate cancer progression that were consistent with patient-based data.

\section{CONCLUSION}

Various ECM components trigger cell responses via multiple downstream signalling pathways. Altered expression of asporin was observed in many cancer types, however, contradictory results on its tumour promoting and suppressive effects require further investigation. Deciphering the role of asporin and other small leucine rich proteoglycans in tumour-stroma interactions is needed for a better understanding of cancer progression and potentially also for novel tumour microenvironment based therapies.

Acknowledgement: This work was supported in part by grants NV15-28628A from the Czech Ministry of Health and NPU I LO1304 from the Czech Ministry of Education. DS was also supported by LF_2016_013.

Author contributions: DS: conceived the idea, literature search, manuscript drafting; GK: literature search and manuscript drafting; ES, PGM were involved in discussion and manuscript drafting; JB supervised the project, made substantial contributions to the concept and manuscript drafting; All authors read and approved the final manuscript.

Conflict of interest statement: None declared. 


\section{REFERENCES}

1. Bosman FT, Stamenkovic I. Functional structure and composition of the extracellular matrix. J Pathol 2003;200(4):423-8.

2. Kharaishvili G, Simkova D, Bouchalova K, Gachechiladze M, Narsia N, Bouchal J. The role of cancer-associated fibroblasts, solid stress and other microenvironmental factors in tumor progression and therapy resistance. Cancer Cell Int 2014;14:41.

3. Jean C, Gravelle P, Fournie JJ, Laurent G. Influence of stress on extracellular matrix and integrin biology. Oncogene 2011;30(24):2697706.

4. Mecham RP. Overview of extracellular matrix. Curr Protoc Cell Biol 2001; Chapter 10:Unit 10.1.

5. Schaefer L, lozzo RV. Small leucine-rich proteoglycans, at the cross road of cancer growth and inflammation. Curr Opin Genet Dev 2012;22(1):56-7.

6. Iozzo RV. Matrix proteoglycans: from molecular design to cellular function. Annu Rev Biochem 1998;67:609-52.

7. Edwards IJ. Proteoglycans in prostate cancer. Nat Rev Uro 2012;9(4):196-206.

8. Schaefer L, Schaefer RM. Proteoglycans: from structural compounds to signaling molecules. Cell Tissue Res 2010;339(1):237-46.

9. Dellett M, Hu W, Papadaki V, Ohnuma S. Small leucine rich proteogly can family regulates multiple signalling pathways in neural development and maintenance. Dev Growth Differ 2012;54(3):327-40.

10. Xu L, Li Z, Liu SY, Xu SY, Ni GX. Asporin and osteoarthritis. Osteoarthritis Cartilage 2015;23(6):933-9.

11. Ni GX, Li Z, Zhou YZ. The role of small leucine-rich proteoglycans in osteoarthritis pathogenesis. Osteoarthritis Cartilage 2014;22(7):896 903.

12. Tian W, Zheng S, Jiang XZ, Wu CA, Wang N, Zhao DH. Asporin, a candidate protein for treatment of disc degenerative disease. Chin Med J (Engl) 2013;126(2):369-72.

13. Ikegawa S. Expression, regulation and function of asporin, a susceptibility gene in common bone and joint diseases. Curr Med Chem 2008;15(7):724-8.

14. Henry SP, Takanosu M, Boyd TC, Mayne PM, Eberspaecher H, Zhou W, de Crombrugghe B, Hook M, Mayne R. Expression pattern and gene characterization of asporin. a newly discovered member of the leucine-rich repeat protein family. J Biol Chem 2001;276(15):12212 21.

15. Lorenzo P, Aspberg A, Onnerfjord P, Bayliss MT, Neame PJ, Heinegard $D$. Identification and characterization of asporin. a novel member of the leucine-rich repeat protein family closely related to decorin and biglycan. J Biol Chem 2001;276(15):12201-11.

16. Yamada S, Murakami S, Matoba R, Ozawa Y, Yokokoji T, Nakahira Y, Ikezawa K, Takayama S, Matsubara K, Okada H. Expression profile of active genes in human periodontal ligament and isolation of PLAP-1, a novel SLRP family gene. Gene 2001;275(2):279-86.

17. Kou I, Nakajima M, Ikegawa S. Binding characteristics of the osteoarthritis-associated protein asporin. J Bone Miner Metab 2010;28(4):395-402.

18. Kizawa H, Kou I, lida A, Sudo A, Miyamoto Y, Fukuda A, Mabuchi A Kotani A, Kawakami A, Yamamoto S, Uchida A, Nakamura K, Notoya $\mathrm{K}$, Nakamura Y, Ikegawa S. An aspartic acid repeat polymorphism in asporin inhibits chondrogenesis and increases susceptibility to osteoarthritis. Nat Genet 2005:37(2):138-44.

19. Nakamura T, Shi D, Tzetis M, Rodriguez-Lopez J, Miyamoto Y, Tsezou A, Gonzalez A, Jiang Q, Kamatani N, Loughlin J, Ikegawa S. Metaanalysis of association between the ASPN D-repeat and osteoarthritis. Hum Mol Genet 2007;16(14):1676-81.

20. Mustafa Z, Dowling B, Chapman K, Sinsheimer JS, Carr A, Loughlin $J$. Investigating the aspartic acid (D) repeat of asporin as a risk factor for osteoarthritis in a UK Caucasian population. Arthritis Rheum 2005;52(11):3502-6.

21. Kaliakatsos M, Tzetis M, Kanavakis E, Fytili P, Chouliaras G, Karachalios T, Malizos K, Tsezou A. Asporin and knee osteoarthritis in patients of Greek origin. Osteoarthritis Cartilage 2006;14(6):609-11.

22. Atif U, Philip A, Aponte J, Woldu EM, Brady S, Kraus VB, Jordan JM, Doherty M, Wilson AG, Moskowitz RW, Hochberg M, Loeser R, Renner $J B, C$ hiano M. Absence of association of asporin polymorphisms and osteoarthritis susceptibility in US Caucasians. Osteoarthritis Cartilage 2008;16(10):1174-7.

23. Valdes AM, Loughlin J, Oene MV, Chapman K, Surdulescu GL,
Doherty M, Spector TD. Sex and ethnic differences in the association of ASPN, CALM1, COL2A1, COMP, and FRZB with genetic susceptibility to osteoarthritis of the knee. Arthritis Rheum 2007;56(1):137-46.

24. Jiang Q, Shi D, Yi L, Ikegawa S, Wang Y, Nakamura T, Qiao D, Liu C, Da $J$. Replication of the association of the aspartic acid repeat polymorphism in the asporin gene with knee-osteoarthritis susceptibility in Han Chinese. J Hum Genet 2006;51(12):1068-72.

25. Shi D, Nakamura T, Dai J, Yi L, Qin J, Chen D, Xu Z, Wang Y, Ikegawa $\mathrm{S}$, Jiang $\mathrm{Q}$. Association of the aspartic acid-repeat polymorphism in the asporin gene with age at onset of knee osteoarthritis in Han Chinese population. J Hum Genet 2007;52(8):664-7.

26. Liu D, Yang Q, Li M, Mu K, Zhang Y. Association of an asporin repeat polymorphism with ankylosing spondylitis in Han Chinese population: a case-control study. Clin Invest Med 2010;33(1):E63-8.

27. Song YQ, Cheung KM, Ho DW, Poon SC, Chiba K, Kawaguchi Y, Hirose Y, Alini M, Grad S, Yee AF, Leong JC, Luk KD, Yip SP, Karppinen J, Cheah KS, Sham P, Ikegawa S, Chan D. Association of the asporin D14 allele with lumbar-disc degeneration in Asians. Am J Hum Genet 2008;82(3):744-7.

28. Bijsterbosch J, Kloppenburg M, Reijnierse M, Rosendaal FR, Huizinga TW, Slagboom PE, Meulenbelt I. Association study of candidate genes for the progression of hand osteoarthritis. Osteoarthritis Cartilage 2013;21(4):565-9.

29. Kalamajski S, Aspberg A, Lindblom K, Heinegård D, Oldberg A. Asporin competes with decorin for collagen binding, binds calcium and promotes osteoblast collagen mineralization. Biochem J 2009;423(1):53-9.

30. Yamada S, Tomoeda M, Ozawa Y, Yoneda S, Terashima Y, Ikezawa K, Ikegawa S, Saito M, Toyosawa S, Murakami S. PLAP-1/asporin, a novel negative regulator of periodontal ligament mineralization. J Biol Chem 2007;282(32):23070-80.

31. Lee EH, Park HJ, Jeong JH, Kim YJ, Cha DW, Kwon DK, Lee SH, Cho JY. The role of asporin in mineralization of human dental pulp stem cells J Cell Physiol. 2011;226(6):1676-82.

32. Sakao K, Takahashi KA, Arai Y, Saito M, Honjyo K, Hiraoka N, Kishida T, Mazda O, Imanishi J, Kubo T. Asporin and transforming growth factor-beta gene expression in osteoblasts from subchondral bone and osteophytes in osteoarthritis. J Orthop Sci 2009;14(6):738-47.

33. Dangaria SJ, Ito $Y$, Luan $X$, Diekwisch TG. Differentiation of neuralcrest-derived intermediate pluripotent progenitors into committed periodontal populations involves unique molecular signature changes, cohort shifts, and epigenetic modifications. Stem Cells Dev 2011;20(1):39-52

34. Önnerfjord $P$, Khabut $A$, Reinholt $F P$, Svensson $O$, Heinegård $D$. Quantitative proteomic analysis of eight cartilaginous tissues reveals characteristic differences as well as similarities between subgroups. J Biol Chem 2012;287(23):18913-24.

35. Kou I, Nakajima M, Ikegawa S. Expression and regulation of the osteoarthritis-associated protein asporin. J Biol Chem 2007;282(44):32193-9.

36. Nakajima M, Kizawa H, Saitoh M, Kou I, Miyazono K, Ikegawa S Mechanisms for asporin function and regulation in articular cartilage. J Biol Chem 2007;282(44):32185-92.

37. Duval E, Bigot N, Hervieu M, Kou I, Leclercq S, Galéra P, Boumediene $\mathrm{K}$, Baugé $\mathrm{C}$. Asporin expression is highly regulated in human chondrocytes. Mol Med 2011;17(7-8):816-23.

38. Tasheva ES, Klocke B, Conrad GW. Analysis of transcriptional regulation of the small leucine rich proteoglycans. Mol Vis 2004;10:758-72.

39. Maris $P$, Blomme $A$, Palacios $A P$, Costanza $B$, Bellahcène $A$, Bianchi E, Gofflot S, Drion P, Trombino GE, Di Valentin E, Cusumano PG, Maweja S, Jerusalem G, Delvenne P, Lifrange E, Castronovo V, Turtoi A. Asporin Is a Fibroblast-Derived TGF- $\beta 1$ Inhibitor and a Tumor Suppressor Associated with Good Prognosis in Breast Cancer. PLoS Med 2015;12(9):e1001871.

40. Lee SD, Choi SY, Lim SW, Lamitina ST, Ho SN, Go WY, Kwon HM. TonEBP stimulates multiple cellular pathways for adaptation to hypertonic stress: organic osmolyte-dependent and -independent pathways. Am J Physiol Renal Physiol 2011;300(3):F707-15.

41. Michl P, Ramjaun AR, Pardo OE, Warne PH, Wagner M, Poulsom R, D'Arrigo C, Ryder K, Menke A, Gress T, Downward J. CUTL1 is a target of TGF(beta) signaling that enhances cancer cell motility and invasiveness. Cancer Cell 2005;7(6):521-32.

42. Schaeffer EM, Marchionni L, Huang Z, Simons B, Blackman A, Yu W, Parmigiani G, Berman DM. Androgen-induced programs for pros- 
tate epithelial growth and invasion arise in embryogenesis and are reactivated in cancer. Oncogene 2008;27(57):7180-91.

43. Vaarala MH, Hirvikoski P, Kauppila S, Paavonen TK. Identification of androgen-regulated genes in human prostate. Mol Med Rep 2012;6(3):466-72.

44. Mackay A, Urruticoechea A, Dixon JM, Dexter T, Fenwick K, Ashworth A, Drury S, Larionov A, Young O, White S, Miller WR, Evans DB, Dowsett M. Molecular response to aromatase inhibitor treatment in primary breast cancer. Breast Cancer Res 2007;9(3):R37.

45. Slaby O, Svoboda M, Fabian P, Smerdova T, Knoflickova D, Bednarikova M, Nenutil R, Vyzula R. Altered expression of miR-21, miR-31, miR-143 and miR-145 is related to clinicopathologic features of colorectal cancer. Oncology. 2007;72(5-6):397-402.

46. Li C, Yue J, Huang X, Chen M, Gao J, Wu B. miR-21 and miR-101 regulate PLAP-1 expression in periodontal ligament cells. Mol Med Rep 2012;5(5):1340-6.

47. Johnston IA, Lee HT, Macqueen DJ, Paranthaman K, Kawashima $C$ Anwar A, Kinghorn JR, Dalmay T. Embryonic temperature affects muscle fibre recruitment in adult zebrafish: genome-wide changes in gene and microRNA expression associated with the transition from hyperplastic to hypertrophic growth phenotypes. J Exp Bio 2009;212(Pt 12):1781-93.

48. Barrett T, Wilhite SE, Ledoux P, Evangelista C, Kim IF, Tomashevsky M, Marshall KA, Phillippy KH, Sherman PM, Holko M, Yefanov A, Lee $\mathrm{H}$, Zhang N, Robertson CL, Serova N, Davis S, Soboleva A. NCBI GEO: archive for functional genomics data sets--update. Nucleic Acids Res 2013;41(Database issue):D991-5.

49. Vallender TW, Lahn BT. Localized methylation in the key regulator gene endothelin-1 is associated with cell type-specific transcriptional silencing. FEBS Lett 2006;580(18):4560-6.

50. Wiesmann F, Veeck J, Galm O, Hartmann A, Esteller M, Knüchel $R$ Dahl E. Frequent loss of endothelin-3 (EDN3) expression due to epigenetic inactivation in human breast cancer. Breast Cancer Res 2009;11(3):R34

51. Ma XJ, Dahiya S, Richardson E, Erlander M, Sgroi DC. Gene expression profiling of the tumor microenvironment during breast cancer progression. Breast Cancer Res 2009;11(1):R7.

52. Lim S, Metzger E, Schüle R, Kirfel J, Buettner R. Epigenetic regulation of cancer growth by histone demethylases. Int J Cancer 2010;127(9):1991-8.

53. Turashvili G, Bouchal J, Baumforth K, Wei W, Dziechciarkova M, Ehrmann J, Klein J, Fridman E, Skarda J, Srovnal J, Hajduch M, Murray P, Kolar Z. Novel markers for differentiation of lobular and ductal invasive breast carcinomas by laser microdissection and microarray analysis. BMC Cancer 2007;7:55.

54. Ma XJ, Wang Z, Ryan PD, Isakoff SJ, Barmettler A, Fuller A, Muir B, Mohapatra G, Salunga R, Tuggle JT, Tran Y, Tran D, Tassin A, Amon P, Wang W, Enright E, Stecker K, Estepa-Sabal E, Smith B, Younger J, Balis U, Michaelson J, Bhan A, Habin K, Baer TM, Brugge J, Haber DA, Erlander MG, Sgroi DC. A two-gene expression ratio predicts clinical outcome in breast cancer patients treated with tamoxifen. Cancer Cell 2004;5(6):607-16.

55. Castellana B, Escuin D, Peiró G, Garcia-Valdecasas B, Vázquez T, Pons C, Pérez-Olabarria M, Barnadas A, Lerma E. ASPN and GJB2 Are Implicated in the Mechanisms of Invasion of Ductal Breast Carcinomas. J Cancer 2012;3:175-83.

56. Klein A, Olendrowitz C, Schmutzler R, Hampl J, Schlag PM, Maass $\mathrm{N}$, Arnold N, Wessel R, Ramser J, Meindl A, Scherneck S, Seitz S. Identification of brain- and bone-specific breast cancer metastasis genes. Cancer Lett 2009;276(2):212-20.

57. Vona-Davis L, Rose DP, Gadiyaram V, Ducatman B, Hobbs G, Hazard $\mathrm{H}$, Kurian S, Abraham J. Breast cancer pathology, receptor status, and patterns of metastasis in a rural appalachian population. J Cancer Epidemiol 2014;2014:170634.

58. Creighton CJ, Li X, Landis M, Dixon JM, Neumeister VM, Sjolund $A$ Rimm DL, Wong $H$, Rodriguez A, Herschkowitz JI, Fan C, Zhang $X$ He X, Pavlick A, Gutierrez MC, Renshaw L, Larionov AA, Faratian D, Hilsenbeck SG, Perou CM, Lewis MT, Rosen JM, Chang JC. Residual breast cancers after conventional therapy display mesenchymal as well as tumor-initiating features. Proc Natl Acad Sci U S A 2009:106(33):13820-5.
59. Martin-Padura I, Gregato G, Marighetti P, Mancuso P, Calleri A, Corsini C, Pruneri G, Manzotti M, Lohsiriwat V, Rietjens M, Petit JY, Bertolini F. The white adipose tissue used in lipotransfer procedures is a rich reservoir of $\mathrm{CD} 34+$ progenitors able to promote cancer progression. Cancer Res 2012;72(1):325-34.

60. Kraman M, Bambrough PJ, Arnold JN, Roberts EW, Magiera L, Jones JO, Gopinathan A, Tuveson DA, Fearon DT. Suppression of antitumor immunity by stromal cells expressing fibroblast activation proteinalpha. Science 2010;330(6005):827-30.

61. Seale P, Kajimura S, Yang W, Chin S, Rohas LM, Uldry M, Tavernier G, Langin D, Spiegelman BM. Transcriptional control of brown fat determination by PRDM16. Cell Metab 2007;6(1):38-54.

62. Yadav H, Quijano C, Kamaraju AK, Gavrilova O, Malek R, Chen W, Zerfas $\mathrm{P}$, Zhigang D, Wright EC, Stuelten C, Sun P, Lonning S, Skarulis $M$, Sumner AE, Finkel T, Rane SG. Protection from obesity and diabetes by blockade of TGF- $\beta /$ Smad3 signaling. Cell Metab 2011;14(1):6779.

63. Li D, Zhang Y, Xu L, Zhou L, Wang Y, Xue B, Wen Z, Li P, Sang J. Regulation of gene expression by FSP27 in white and brown adipose tissue. BMC Genomics 2010;11:446.

64. Xu L, Xia X, Arshad M, Zhou L. Gene expression profile in the fat tissue of Fsp27 deficient mice. Genom Data 2015;5:326-8.

65. Simkova D, Kharaishvili G, Korinkova G, Ozdian T, SuchankovaKleplova T, Soukup T, Krupka M, Galandakova A, Dzubak P, Janikova M, Navratil J, Kahounova Z, Soucek K, Bouchal J. The dual role of asporin in breast cancer progression. Oncotarget 2016, accepted on 29th June 2016. doi: 10.18632/oncotarget.10471

66. Satoyoshi R, Kuriyama S, Aiba N, Yashiro M, Tanaka M. Asporin activates coordinated invasion of scirrhous gastric cancer and cancerassociated fibroblasts. Oncogene 2015; 34(5):650-60.

67. Rajkumar T, Vijayalakshmi N, Gopal G, Sabitha K, Shirley S, Raja UM, Ramakrishnan SA. Identification and validation of genes involved in gastric tumorigenesis. Cancer Cell Int 2010;10:45.

68. Ding Q, Zhang M, Liu C. Asporin participates in gastric cancer cell growth and migration by influencing EGF receptor signaling. Oncol Rep 2015;33(4):1783-90.

69. Turtoi A, Musmeci D, Wang Y, Dumont B, Somja J, Bevilacqua G, De Pauw E, Delvenne $P$, Castronovo V. Identification of novel accessible proteins bearing diagnostic and therapeutic potential in human pancreatic ductal adenocarcinoma. J Proteome Res 2011;10 430213.

70. Cima I, Schiess R, Wild P, Kaelin M, Schüffler P, Lange V, Picotti $P$, Ossola R, Templeton A, Schubert O, Fuchs T, Leippold T, Wyler S, Zehetner J, Jochum W, Buhmann J, Cerny T, Moch H, Gillessen S, Aebersold R, Krek W. Cancer genetics-guided discovery of serum biomarker signatures for diagnosis and prognosis of prostate cancer. Proc Natl Acad Sci U S A 2011;108:3342-7.

71. Klee EW, Bondar OP, Goodmanson MK, Dyer RB, Erdogan S, Bergstralh EJ, Bergen HR, Sebo TJ, Klee GG. Candidate serum biomarkers for prostate adenocarcinoma identified by mRNA differences in prostate tissue and verified with protein measurements in tissue and blood. Clin Chem 2012;58(3):599-609.

72. Best CJ, Gillespie JW, Yi Y, Chandramouli GV, Perlmutter MA, Gathright $Y$, Erickson HS, Georgevich L, Tangrea MA, Duray PH, González S, Velasco A, Linehan WM, Matusik RJ, Price DK, Figg WD, Emmert-Buck MR, Chuaqui RF. Molecular alterations in primary prostate cancer after androgen ablation therapy. Clin Cancer Res 2005:11(19 Pt 1):6823-34

73. Stanbrough M, Bubley GJ, Ross K, Golub TR, Rubin MA, Penning TM, Febbo PG, Balk SP. Increased expression of genes converting adrenal androgens to testosterone in androgen-independent prostate cancer. Cancer Res 2006;66(5):2815-25.

74. Hurley PJ, Sundi D, Shinder B, Simons BW, Hughes RM, Miller RM, Benzon B, Faraj SF, Netto GJ, Vergara IA, Erho N, Davicioni E, Karnes RJ, Yan G, Ewing C, Isaacs SD, Berman DM, Rider JR, Jordahl KM, Mucci LA, Huang J, An SS, Park BH, Isaacs WB, Marchionni L, Ross AE, Schaeffer EM. Germline Variants in Asporin Vary by Race, Modulate the Tumor Microenvironment, and Are Differentially Associated with Metastatic Prostate Cancer. Clin Cancer Res 2016;22(2):448-58. 